\title{
Food services and customer loyalty in the hospitality industry
}

\section{Os serviços de alimentação e a lealdade na indústria de hospitalidade}

\author{
Vitor Roslindo Kuhn \\ University of Vale do Itajaí, Brazil \\ vitorroslindo@yahoo.com.br \\ Antônio Carlos Benett \\ University of Vale do Itajaí, Brazil \\ antoniobenetti@edu.univali.br \\ Sara Joana Gadotti dos Anjos \\ University of Vale do Itajaí, Brazil, sara@univali.br \\ Pablo Flores Limberger \\ University of Vale do Itajaí, Brazil, pablofl@univali.br
}

\begin{abstract}
Understanding the needs and expectations of customers is a major competitive tool. Their perception of food service quality has been increasingly studied. An understanding of this topic can help managers to develop strategies to improve customer satisfaction and increase loyalty. The objective of the research is to verify the predictive power of food service quality elements on customer loyalty intentions. This research is exploratory with quantitative approach applied to a hotel in Balneário Camboriú. We used multiple regression analysis to achieve results. The constructs analysed were: Service Brigade; Management; Menu; Ancillary Services; and Physical Features, which did not prove to be significant to Loyalty. The most significant construct was Service Brigade, a finding consistent with studies that show that employee training is key to increase the level of satisfaction and loyalty.

Keywords: Loyalty, food service, lodging industry, Brazil, multiple regression.
\end{abstract}

\section{Resumo}

Compreender as expectativas e desejos do cliente é uma grande ferramenta competitiva. A sua perceção acerca dos aspetos de qualidade em serviço de alimentação vem sendo estudada com maior frequência. Está discussão auxilia o gestor elaborar estratégias que melhorem a satisfação do cliente e aumentem lealdade. $\mathrm{O}$ objetivo da pesquisa foi verificar o poder prever a intenção de lealdade através dos elementos de qualidade do serviço de alimentação. A metodologia adotada é uma pesquisa exploratória com abordagem quantitativa aplicada em um hotel de Balneário Camboriú. Utilizou-se de análise de regressão múltipla para alcançar os resultados. Os constructos analisados foram: Brigada de serviço; Gerência; Cardápio; Serviços auxiliares; e Aspetos físicos, este não se mostrou significativo em medir a Lealdade. O fator com melhor resultado foi Brigada de serviço, corroborando com estudos que concluem que o treinamento dos funcionários é vital para alavancar o nível de satisfação e lealdade.

Palavras-chave: Lealdade, serviço de alimentação, meios de hospedagem, Brasil, regressão múltipla.

\section{Introduction}

Tourism is considered an alternative for economic development since it creates jobs and revenue. Moreover, tourism has become one of the most sophisticated businesses, creating a diversified offer, linking several factors, and becoming a privileged space of production. To assess the tourism potential of a region we must consider the physical infrastructure and logistic services for the reception of tourists, including accommodation and food services.

In the Brazilian context, tourism has broadened its scope, encompassing elements such as natural landscapes, diversified offers of cultural attractions, gastronomy, and entertainment. Brazilians are known for their hospitality and friendliness, putting the country on the tourist map.

Food and accommodation services help to understand the relationship between companies and customers, i.e. tourists. Quality, variety, and promptness are parameters to assess how tourists are served, the quality of the facilities offered by hotels, and the relationship and interaction between these elements.

Like any other consumer, tourists are demanding in terms of quality and have increasing experience in terms of accommodation. Thus, guests are able to make comparisons and critical assessment of all aspects and elements, including the food, a key factor that, besides health, adds to the enjoyment of the stay

There are numerous factors that explain the attention given to food in accommodation establishments. Eating habits are an expression of a people's beliefs and traditions and are linked to geography and availability. They are affected by economic, religious, psychological, and convenience factors. During the 21st century, customs and traditions have been strongly modified and tourists are increasingly segmented in terms of needs, behaviours, and interests making it more difficult for tourism professionals to offer their services and prioritize investments.

These factors influence the creation of a service able to address a wide and diversified array of customer needs. The 
accommodation establishments must meet the needs and expectations of consumers, however, the services offered differ within the industry. Each consumer has different interests in different moments and situations, and there is room for all kinds of options, from upscale restaurants to budget or fastfood eateries.

Considering these challenges, it is essential to understand the menu selection, the facilities, the service staff, and other complementary services that compose what guests receive. In this way one can understand how the structure of quality and customer service are designed in hospitality.

Service is any act or performance, essentially intangible, offered to satisfy a need, provided it does not entail the production of material goods. Thus, service is the set of activities carried out by a company to meet the expectations of customers. Among its characteristics the following stand out: intangibility, heterogeneity, inseparability, perishability, and lack of ownership. Usually when a service is designed the main concern is the benefit sought by the customer (essential service), i.e., the ability to solve a problem. However, customers assess the quality of service more deeply. They analyse the level of perceived service, which involves the professional who performed it, quality, process, value, and location; as well as the extended service, which includes additional benefits and services.

Recently, the key to success in hospitality has shifted from focusing on location and facilities to service quality where employees play a very important role in customer satisfaction. That is, the feeling a consumer has as a result of postconsumption evaluation. Satisfaction is recognized as one of the main factors that determine the development of customer loyalty. Research in the field of hospitality has confirmed the direct link between customer satisfaction and the development of customer loyalty (Untaru, Ispas, \& Neacsu, 2012)

Overall satisfaction, as an antecedent of loyalty, is widely considered as a competitive advantage and an effective measure for business development. A dissatisfied customer has an array of similar services at his or her disposal, while a company with loyal customers can remain more competitive. Newly acquired guests will return if they are satisfied with the services received and if they identify the hotel as a special place. These guests become an effective source of positive word-of-mouth, spreading the word about the hotel and its qualities (Neto, Filho, \& Cabral, 2009). In this context, satisfaction management is essential to loyalty and becomes of utmost importance to the business.

The aim of this research was to verify the predictive power of food service quality on customer loyalty intentions, in accommodation establishments. The study was applied in a 4star hotel in Balneário Camboriú, in the coast of the state of Santa Catarina, Brazil. The city was chosen as object of study because it is an important destination for international and domestic tourism, with beautiful beaches and busy nightlife.

This paper is composed of five sections. The first section considers introductory aspects. The next section examines the theoretical framework regarding the topics studied: food service, quality, satisfaction, and loyalty, as well as the relationship between them. Sections three and four present the methodology and the results of the study, respectively. The last section presents the conclusions.

\section{Loyalty and food services}

The food industry is an essential part of hospitality that contributes to satisfy the physiological needs and can, as well, provide a tourism dining experience. Often the main tourist attraction of a region is its gastronomy, considering that society has developed to the point of portraying the act of cooking as an art and as a way of satisfying intellectual and emotional needs, besides physiology (Krause, 2014). Understanding the food service as part of the tourist offer, makes it possible to analyse its importance not only as a service provided but also as a tourist attraction; as a form of cultural expression through typical dishes that arouse the curiosity of tourists. As a result, traditional cuisine is increasingly recognized as a valuable component of the intangible heritage of a people (Ferro, 2013).

The food and beverage service is of great importance in the hospitality industry, accounting for a high percentage of the organization's revenue, generating job opportunities and developing the location. This profitability happens if the organization maintains a level of excellence, competent management, resulting in a quality service (Castelli, 2003; Chand \& Kapoor, 2014). Food and beverage management becomes prominent, being responsible for outlining objectives and strategies, dealing with staff and customers, and where the interpersonal relationships are major features (Cândido \& Vieira, 2003).

Although the cuisine is, in fact, an art form, the process of creating a menu suitable for the clientele, in a heterogeneous consumer environment such as hotels and hostels, must be based on product and customer service quality. Among the services provided by hotels and hostels, the breakfast stands out. This is usually the only meal included in the room rate, and it stands out as an amenity that has a major influence on consumers' choice of a hotel. Because it is the first meal of the day, after a long period of fasting during sleep, breakfast is of particular importance (Barreto \& Cé, 2014; Trancoso, Cavalli, \& Proença, 2010). In hotels, breakfast is also one of the most important moments of the day, it arouses the curiosity of guests and can be strategic to the company. It is possible to make an impression and surprise the customer during breakfast both in terms of product and service quality. It is also a unique moment for the hotelier to seduce the guest (Trancoso, 2008).

The level of demand of customers is continuously growing. Once a need is met others emerge, making it crucial for service providers to understand customer expectations and perceptions, as well as the factors that influence their evaluation and satisfaction with the service provided (Chand \& Kapoor, 2014). It is important to emphasize that hotel restaurant services should 
seek to continually improve service excellence, paying special attention to its tangible aspects and to raise staff awareness of quality issues (Silva, Medeiros, Costa, 2009).

The evaluation of the food service quality in the accommodation establishments affects the perception of quality processes, which, in turn, affect the indicators that guide the what, and why of customer service projects. This quality is associated with intrinsic characteristics of food (nutritional and sensory quality), safety (sanitary quality), service (customer-company relationship) and price. Some factors that can affect quality are linked to high employee turnover, low-quality food, low-cost production and unskilled, untrained and not specifically prepared labour for this sector. In addition, quality becomes what the organization decides to adopt to guide its actions and improve the relationship with customers (Untaru et al., 2012). Certainly, the management will conduct the processes and, thus, quality will be reflected on the results of these applications.

Quality is a quest for perfection with the purpose of understanding exactly what will please customers, increasingly aware of the amenities and of the variety of companies in the market. When we evaluate an organization, we are examining and analysing the productive process to adequate it, fast and efficiently to the quality requirements determined by that process (Paladini, 2012). Quality is inherent to the product or service, but it is assessed by the customer. Therefore, the product or service quality will depend on the customer's perception, which will always be subjective. Because of this, the constant search for service quality can boost competitiveness of hotel companies.

The enhancement of the quality management process and the search for competitive advantages must: emphasize the added value by methods difficult to copy by competitors; continue to impress guests; and prioritize quality, which depends on training, execution, and control, as well as the allocation of sufficient resources to achieve and maintain leadership. The service has to add value for the guest, i.e. to satisfy their needs because they will pay the company a higher value than the cost to provide it, thus allowing for the entrepreneurs to secure a positive cash flow (Araujo, 2001).

Therefore, in an increasingly competitive market and demanding consumers it is very difficult for an enterprise to survive without satisfying the wants and needs of its customers and searching for options that will exceed their expectations (Untaru et al. 2012). To meet these requirements, it is necessary to invest in quality, analyse how hotel customers perceive quality and what are the tools used by companies to measure customers' satisfaction with the services provided, as well as analyse whether such tools or methods are appropriate to achieve customer satisfaction. Customer satisfaction is defined as the person's feelings of pleasure resulting from comparing a product's perceived performance in relation to their expectations. The dissatisfied customer is the one who perceives the performance below their expectations. If the performance meets the expectation, the customer will be satisfied while if performance is higher than expected, this customer will be very satisfied (Kotler \& Keller, 2013; Parasuraman, Zeithaml, \& Berry, 1985).

In this context, it is concluded that a quality service generates satisfaction and meets the customers' expectations. Therefore, quality can be understood as satisfaction, longing, adequacy, compliance, and exceeding customer expectations. For a company to succeed in a competitive market it must offer quality products and have an ethical and leadership attitude, working together with the employees to meet the goals, providing training and qualification for staff, and having prices compatible to the value of delivered products (Silva et al., 2009).

The main difference in defining the quality of service delivery lies in the subjectivity and difficulty of determining what quality is, since customers react differently to what appears to be the same service standard. Each customer has a certain perception about quality, and often this difference is due to the customer's mood at the time the service is provided. Customers have different quality standards (Untaru et al., 2012).

It is important to underline that service quality can be perceived by customers through its tangible and intangible components. The tangible features of service are those aspects that the customer sees, e.g. the physical appearance of a hotel, lighting, decoration, cleanliness of the environment, uniform, and presentation of employees. The intangible components are based on kindness, cordiality, and cooperation during the service provision (Untaru et al., 2012).

A service of excellence strengthens customer loyalty and attracts new customers. Loyalty may be related to the provision of quality of service, where besides the hotel the tourist benefits from a set of infrastructures that promotes its use, thus getting to know the activities, traditions, and local lifestyle.

Loyalty is part of relationship marketing and it includes servicing, maintaining, and increasing customer relationship, whose goal is to establish long-term relationships that translate into customer loyalty (Behara, Fontenot, \& Gresham, 2002). The retention costs can be much lower, promoting greater profitability, since loyal customers are less prone to seek alternatives, more resistant to persuasion by competitors and more likely to engage in positive word of mouth communication (Dick \& Basu, 1994; Schiffman \& Kanuk, 2000). The hotel business depends on the relationships with the guests. Customers will keep on coming back if they are satisfied with the services provided and if they consider the hotel unique. These guests become a tool for promoting the hotel and the qualities that appeal to them (Petrocchi, 2007).

Several studies have emphasized that customer loyalty acts as a strong antecedent of organizational performance, besides being a source of competitive advantage. In addition to increasing revenue, greater customer loyalty may lower 
acquisition and business maintenance costs, leading to higher profitability (Rust, Zeithami, \& Lemon, 2003). It is a deep commitment to repeat a purchase or favour a product or service in the future, repeating a brand or a purchase from the same set of brands, despite situational influences and marketing efforts with potential to change the behaviour (Neto et al., 2009, Oliver, 1999).

Service loyalty can arise from an outstanding service that delights the customer. This can happen in situations involving extensive interpersonal encounters. Research on service also found that loyalty can arise from the comfort of the consumer. Consumer comfort is a psychological state in which consumer anxiety about a service has been slowed down, and he feels calm, relaxed, and unconcerned about service encounters and a specific provider (Abdalla, Altaf, Troccoli, Nóbrega, \& Cruz, 2013). Regarding research on food and beverage service quality, we made a literature survey on this topic. In Table 1 we present relevant studies within the scope of this paper.

Table 1 - Research on food and beverage service quality

\begin{tabular}{|c|c|c|c|c|}
\hline Authors & Year & Objective & Methodology & Main dimensions analysed \\
\hline (Soriano, 2003) & 2003 & $\begin{array}{l}\text { To determine the degree of customer } \\
\text { satisfaction in relation to the } \\
\text { restaurant sector in Spain }\end{array}$ & $\begin{array}{l}\text {-SERVQUAL } \\
\text {-Likert scale ( } 5 \text { points) }\end{array}$ & $\begin{array}{l}\text { * Reservation system } \\
\text { * Physical attributes of space } \\
\text { * Attributes/food quality } \\
\text { * Service brigade } \\
\text { * Management } \\
\text { * Ancillary services }\end{array}$ \\
\hline (Madanoglu, 2004) & 2004 & $\begin{array}{l}\text { To validate two restaurant quality } \\
\text { dimensions } \\
\text { Personal behaviour/ attitude and } \\
\text { physical quality. }\end{array}$ & $\begin{array}{l}\text { - SERVPERF } \\
\text {-Confirmatory factor analysis } \\
\text {-Likert scale ( } 5 \text { points) }\end{array}$ & $\begin{array}{l}\text { * Physical features } \\
\text { * Attitudes employees/services }\end{array}$ \\
\hline $\begin{array}{l}\text { (Defranco, } \\
\text { Wortman, Lam, \& } \\
\text { Countryman, 2005) }\end{array}$ & 2005 & $\begin{array}{l}\text { To compare the perceived ambiance } \\
\text { by the guests with relation to food } \\
\text { and beverage service in two hotels. }\end{array}$ & $\begin{array}{l}\text {-Qualitative method } \\
\text {-SERVPERF } \\
\text { - Likert scale ( } 5 \text { points) }\end{array}$ & $\begin{array}{l}\text { * Physical attributes of food } \\
\text { * Physical attributes of space } \\
\text { * Behaviour people/service } \\
\text { * Customer behaviour }\end{array}$ \\
\hline (Barros, 2013) & 2013 & $\begin{array}{l}\text { To develop a model to evaluate and } \\
\text { classify service quality provided by } \\
\text { restaurants from the customer's } \\
\text { perspective. }\end{array}$ & $\begin{array}{l}\text { - Adapted from SERVPERF } \\
\text { - DINNERPERF }\end{array}$ & $\begin{array}{l}\text { * Reliability } \\
\text { * Receptivity } \\
\text { * Security } \\
\text { * Empathy } \\
\text { * Product quality } \\
\text { * Environment conditions } \\
\text { * Cleanliness } \\
\text { * Facilities } \\
\text { * Layout } \\
\text { * Electronic equipment } \\
\text { * Seating comfort } \\
\text { * Employees } \\
\text { * Tableware } \\
\text { * Environmental actions } \\
\text { * Access for disabled people }\end{array}$ \\
\hline (Chin \& Tsai, 2013) & 2013 & $\begin{array}{l}\text { To develop a model for assessing } \\
\text { service quality for upscale restaurants } \\
\text { and international hotel chains. }\end{array}$ & $\begin{array}{l}\text { - Delphi method } \\
\text {-SERVQUAL }\end{array}$ & $\begin{array}{l}\text { * Tangible aspects } \\
* \text { Safety } \\
\text { * Empathy } \\
\text { * Innovation } \\
\text { * Trust } \\
\text { * Response capability }\end{array}$ \\
\hline $\begin{array}{l}\text { (Chand \& Kapoor, } \\
\text { 2014) }\end{array}$ & 2014 & $\begin{array}{l}\text { To compare the importance given to } \\
\text { food and beverage service between } \\
\text { hotel chains and resorts in India: the } \\
\text { management perspective. }\end{array}$ & $\begin{array}{l}\text {-Quantitative method } \\
\text {-SERVPERF } \\
\text { - Likert scale ( } 5 \text { points) }\end{array}$ & $\begin{array}{l}\text { * Dinner } \\
\text { * Room service } \\
\text { * Bar } \\
\text { * Banquets/events }\end{array}$ \\
\hline $\begin{array}{l}\text { (Ma, Qu, \& Eliwa, } \\
\text { 2014) }\end{array}$ & 2014 & $\begin{array}{l}\text { To examine if there are gender } \\
\text { differences regarding restaurant } \\
\text { experience, and their relationship } \\
\text { with loyalty aspects. }\end{array}$ & $\begin{array}{l}\text {-SERVPERF } \\
\text { - Likert scale (7 points) } \\
\text {-Pilot-test (Cronbach's alpha) } \\
\text {-Convenience sampling } \\
\text { - Structural equation modelling }\end{array}$ & $\begin{array}{l}\text { * Food quality } \\
\text { * Attitudes Person/Service } \\
\text { * Establishment image } \\
\text { * Satisfaction/customer behaviour }\end{array}$ \\
\hline $\begin{array}{l}\text { (Peng, Chen, \& } \\
\text { Hung, 2017) }\end{array}$ & 2017 & $\begin{array}{l}\text { To examine the influence of a } \\
\text { teppanyaki restaurant features } \\
\text { (service and food quality; } \\
\text { environment; and Chef's image) on } \\
\text { positive and negative emotions and } \\
\text { their effect on customer loyalty. }\end{array}$ & $\begin{array}{l}\text {-Quantitative method } \\
\text { - Likert scale (7 points) } \\
\text {-Purposive sampling } \\
\text {-Confirmatory analysis } \\
\text { (Cronbach's alpha) } \\
\text { - Structural equation modelling }\end{array}$ & $\begin{array}{l}\text { * Food quality } \\
\text { * Service quality } \\
\text { * Environment } \\
\text { * Interaction with other customers } \\
\text { * Chef's image } \\
\text { *Positive emotions } \\
\text { * Negative emotions } \\
\text { *Loyalty }\end{array}$ \\
\hline
\end{tabular}

Source: The authors. 
Two of the studies have as objective the development of quality evaluation models for food services (one in restaurants and the other in luxury hotel restaurant chains), using a methodology based on both SERVQUAL and SERVPERF. The main variables analysed were: trust; empathy; safety; innovation; tangible aspects; response capacity (Barros, 2013, Chin \& Tsai, 2013). The study by Chan and Kapoor (2014) aims at comparing the importance given by the managers of hotel chains and resorts in India to the following service groups: Dinner; Bedroom; Bar; and Banquets/events. The objective of the study by Peng, Chen and Hung (2017) is to examine the influence of the restaurant aspects with teppanyaki service on positive and negative emotions and their effect on customer loyalty, the result generated a structural equation, using a methodology similar to that of the study by Ma, Qu and Eliwa (2014).

Among the most used methodologies are those based on SERVPERF using a Likert scale (Ma et al., 2014, Madanoglu, 2004 and Soriano, 2003) and the main variables examined are:

- Physical Features of the Environment, such as: Adequate size of the space; Large circulation areas; Furniture - good presentation; Comfortable seats; Cutlery - Consistent; Cutlery - Maintained; Proper cleaning; Lighting; Background music; Noise; Temperature; Decoration - nice; Decoration appropriate; Decoration - matching with the hotel; and Outside landscape.

- Quality of the Menu, such as: Variety of dishes; Variety of beverages; Presentation; Flavour; Fresh fruit; Size of the portions; and Temperature of the food.

- Service Brigade, such as: Waiting time; Readiness; Speed of service; Attentive staff; Personal presentation; Knowledge of the product; Communication with the customer; and Time dedicated.

- Management, such as: Presence in the place; In contact with customer; Ability to solve; and Speed of resolution.

- Ancillary Services, such as: Parking; Safe environment; Opening hours; and Bathrooms.

- Customer Loyalty, such as: Food is good value for money; Coming back to hotel due to food service; and Recommendation of the hotel food service.

The perception of food quality and the physical features of the environment are the most frequent variables in the studies.
From these variables presented in the above studies, we developed the data collection instrument for the present research, adapting the questions of Soriano (2003), Madanoglu (2004), Barros (2013), Ma, Qu and Eliwa (2014), Peng, Chen and Hung (2017), designing a questionnaire to measure customer perception of food service quality aspects through the following categories: Physical Features of the Environment; Quality of the Menu; Service Brigade; Management; and Ancillary Services; and test them as predictors of customer loyalty intention.

\section{Methodology}

The research is quantitative and descriptive. In order to meet the objective of the study, we conducted a literature review and a self-administered questionnaire survey. The collection instrument was divided into seven parts, based on Soriano's (2003) study, adapting variables used in the research described in the theoretical framework. The first part of the questionnaire assessed the personal data of respondents such as: age; gender; nationality; and marital status. Parts 2 to 7 referred to the guests' perception regarding food service quality. Guests were addressed at breakfast time, in the hotel studied, and the variables were grouped into: Physical Features of the Environment; Quality of the Menu; Service Brigade; Management; Ancillary Services; and Customer Loyalty. A 5point Likert scale was used for measurement. The questionnaire was applied during the breakfast because this service is included in the room rate and thus, there is a greater participation of guests.

The quality of the physical features of the environment was measured by fifteen variables, adapted from the studies by Soriano (2003), Barros (2013) and Ma, Qu and Eliwa (2014). To assess the quality of the menu we used seven variables based on research by Soriano (2003), Barros (2013), Ma, Qu and Eliwa (2014) and Peng, Chen and Hung (2017). In the section regarding the service brigade, we adapted eight variables from Soriano (2003) and Madanoglu (2004). The questions regarding management and ancillary services were evaluated through four variables each, based on Soriano's (2003) research. Finally, we measured customer loyalty by three variables, using the studies of Ma, Qu and Eliwa (2014), and Peng, Chen and Hung (2017) (Table 2).

Table 2 - Summary of constructs

\begin{tabular}{|l|l|l|}
\hline \multicolumn{1}{|c|}{ Construct } & \multicolumn{1}{c|}{ Variables } & \multicolumn{1}{c|}{ Authors } \\
\hline & Size & \\
\hline & Mobility & \\
& Furniture & \\
Comfort & (Barros, 2013; Ma et al., 2014; \\
Matching cutlery & Soriano, 2003) \\
\hline Physical Features & Conservation & \\
& Cleanliness & \\
& Lighting & \\
& Background music & \\
& Noise & \\
& Temperature & \\
Nice decoration &
\end{tabular}




\begin{tabular}{|c|c|c|}
\hline & $\begin{array}{l}\text { Appropriate decoration } \\
\text { Matching decoration } \\
\text { Outside landscape }\end{array}$ & \\
\hline Quality of the Menu & $\begin{array}{l}\text { Variety of dishes } \\
\text { Variety of beverages } \\
\text { Presentation } \\
\text { Flavour } \\
\text { Fresh fruits } \\
\text { Size of the portion } \\
\text { Food temperature }\end{array}$ & $\begin{array}{l}\text { (Barros, 2013; Ma et al., 2014; } \\
\text { Peng et al., 2017; Soriano, } \\
\text { 2003) }\end{array}$ \\
\hline Service Brigade & $\begin{array}{l}\text { Waiting time } \\
\text { Readiness } \\
\text { Speed of service } \\
\text { Attentive staff } \\
\text { Personal presentation Knowledge of the } \\
\text { product } \\
\text { Communication with the customer } \\
\text { Time dedicated }\end{array}$ & $\begin{array}{l}\text { (Madanoglu, 2004; Soriano, } \\
\text { 2003) }\end{array}$ \\
\hline Management & $\begin{array}{l}\text { Presence in the place } \\
\text { Contact with the customer } \\
\text { Ability to solve } \\
\text { Speed of resolution }\end{array}$ & (Soriano, 2003) \\
\hline Ancillary Services & $\begin{array}{l}\text { Parking } \\
\text { Safety } \\
\text { Opening hours } \\
\text { Bathrooms }\end{array}$ & (Soriano, 2003) \\
\hline Loyalty & $\begin{array}{l}\text { Return } \\
\text { Recommendation } \\
\text { Value }\end{array}$ & $\begin{array}{l}\text { (Ma et al., 2014; Peng et al., } \\
\text { 2017) }\end{array}$ \\
\hline
\end{tabular}

The target population was foreign and Brazilian guests staying in a 4-star hotel located in the central area of the city of Balneário Camboriú, two blocks away from the beach. We used a nonprobabilistic convenience sample, because of the easy access to guests by the researchers. The questionnaire was written in three languages (Portuguese, English, and Spanish) and handed out directly to the guests at breakfast time, many of them answered on the spot and the others took it to their rooms and returned it the next day. This stage occurred between May 12 and 26, and June 10 and 13, 2016. A total of 250 questionnaires were distributed, of which 215 were returned. After discarding the questionnaires lacking information about loyalty (focus of the comparison analysis) we obtained 209 , representing a rate of $83.60 \%$ valid questionnaires for data analysis. After applying the questionnaire and obtaining a satisfactory number of respondents, we analysed the data using IBM SPSS Statistics 22 software.

Two steps of data analysis were performed to test the predictive power of food service quality elements on guests' loyalty intention. Firstly, based on the authors used to design the questionnaire, the variables were condensed into six constructs and a reliability analysis was performed. This method helps the researcher to test how well a construct represents reality and its power of measurement through a set of variables (Hair, Black, Babin, Anderson, \& Tatham, 2009).

Secondly, we used multiple regression technique to verify the correlation and predictive power of constructs. The method allows to explain if there is a correlation between two or more variables, clarifying if this is a positive or negative correlation. It also verifies the power of an independent variable or set of variables (also known as predictor) in measuring a dependent variable (also outcome or result variable). The predictive model is fitted based on the following generic equation: Result = (Model) + Error; wherein the model represents the predictive variables and their respective coefficients. This means that the expected result of a person is calculated from the fit of the data to the model plus some type of error (Field, 2009). The multiple regression analysis was performed from the Loyalty function as dependent variable and the Physical Features, Menu Quality, Service Brigade, Management, and Ancillary Services as Predictive Variables (Table 3).

Table 3 - Multiple regression model equation

\begin{tabular}{|c|c|c|c|c|c|c|c|c|c|}
\hline LOYALTY & $=B 0$ & $+B 1$ & $\begin{array}{l}\text { Physical } \\
\text { Features }\end{array}$ & $+B 2$ Menu & $+B 3$ & $\begin{array}{l}\text { Service } \\
\text { Brigade }\end{array}$ & +B4 Management & $+B 5$ & $\begin{array}{l}\text { Ancillary } \\
\text { Services }\end{array}$ \\
\hline
\end{tabular}

Source: The authors.

\section{Results}

The first part of the questionnaire addressed questions regarding the demographic profile of the sample, with data about: gender; age; nationality; and marital status. The remainder of the questionnaire assessed the guests' perception of food service quality offered by the hotel and their loyalty 
intention toward the establishment. Afterwards, we present the analysis of the relationship between the prediction of service aspects and the loyalty of the guest.
The sample is composed of 209 valid respondents. More than half of the sample are men (53.59\%) and aged between 18 and 35 years $(58.37 \%)$. Less than $9 \%$ were foreigners; the majority (57.41\%) were married and $37.80 \%$ were single (Table 4 ).

Table 4 - Sample profile

\begin{tabular}{|l|l|l|}
\hline & \multicolumn{2}{|c|}{. } \\
\hline & 209 & 100 \\
\hline Gender & & \\
\hline -Male & 112 & 53.59 \\
\hline -Female & 97 & 46.41 \\
\hline Age & & \\
\hline - 18 to 35 years & 122 & 58.37 \\
\hline - 36 to 50 years & 60 & 28.70 \\
\hline - over 51 years & 27 & 12.93 \\
\hline Nationality & & \\
\hline -Brazilian & 192 & 91.86 \\
\hline -Foreigner & 17 & 08.14 \\
\hline Marital status & & \\
\hline -Single & 79 & 37.80 \\
\hline -Married & 120 & 57.41 \\
\hline -Other & 10 & 04.79 \\
\hline
\end{tabular}

Source: The authors.

A total of 38 variables for assessing the perception of food service quality were condensed in the following constructs: ancillary services; menu; management; service brigade; and physical aspects. This division was based on Soriano (2003), Barros (2013), Ma et al. (2014) and Madanoglu's (2004) surveys. The construct that measures the intention of loyalty was based on 3 variables from Ma et al. (2014). The results of the confirmatory analysis, using the Cronbach's alpha method, are shown in Table 5. Cronbach's alpha values above 0.700 are desirable (Field, 2009; Hair et al., 2009), having occurred in all analysed constructs which demonstrates that they are reliable to represent and measure reality through their sets of variables.

Table 5 - Reliability analysis

\begin{tabular}{|l|c|c|c|}
\hline \multicolumn{1}{|c|}{ Construct } & Cronbach's alpha & Cronbach's alpha (standardized) & No. of items \\
\hline Physical Features & 0.906 & 0.908 & 15 \\
\hline Menu & 0.876 & 0.877 & 07 \\
\hline Service Brigade & 0.853 & 0.854 & 08 \\
\hline Management & 0.838 & 0.842 & 04 \\
\hline Ancillary Services & 0.700 & 0.705 & 04 \\
\hline Loyalty & 0.809 & 0.809 & 03 \\
\hline
\end{tabular}

Source: The authors.

Table 6 presents the results of regression analysis wherein Loyalty was treated as the dependent variable; for the analysis, we chose the backward method. In this approach, all predictors of the model are placed and then the contribution of each is checked for significance, the values greater than 0.05 are removed, then the model is re-estimated (Field, 2009). Model 1 represents the analysis using as predictors the five constructs listed in the theoretical model, the $\mathrm{R}^{2}$ value was 0.471 indicating the variance in the result explained by the predictive variables; higher values indicate a stronger regression model (Hair et al., 2009; Mann, 2015). It was necessary to perform the calculation with a second model since physical features construct had a significance higher than $0.05(0.873)$ in the results of the regression coefficient. In the second model, the $\mathrm{R}^{2}$ value was not much different, 0.470 , and accounted for $47 \%$ of the variation of loyalty intention. However, the $F$ value of Model 2 was 45.307 , which indicates it is better adapted to measure loyalty intention than Model 1 . The $\mathrm{F}$ change is a measure that demonstrates how much the model improved in the prediction of the result, thus a good model has high $\mathrm{F}$ change values (Field, 2009).

\section{Table 6 - Summary of the multiple regression model}

\begin{tabular}{|l|c|c|c|c|}
\hline & $\mathbf{R}^{\mathbf{2}}$ & Adjusted $\mathbf{R}^{\mathbf{2}}$ & F change & Sig \\
\hline Model 1* & 0.471 & 0.457 & 36.077 & 0.000 \\
\hline Model 2** & 0.470 & 0.460 & 45.307 & 0.000 \\
\hline
\end{tabular}

*. Predictors: ancillary services; menu; management; service brigade; and physical features.

**. Predictors: ancillary services; menu; management; and service brigade. Dependent variable: loyalty Source: The authors. 
Table 7 shows the summary of the coefficients for the regression analysis. In Model 1 the Physical Features construct obtained a significance value above the desirable value of 0.05 , which is the reason for calculating a second model. All other aspects showed values below 0.05 . After performing a new analysis (Model 2) excluding Physical Features, the significance of the other constructs and their coefficients did not undergo significant changes, resulting in a better-quality model with loyalty intention with positive correlation.

Table 7 - Coefficient of Multiple Regression

\begin{tabular}{|l|l|l|l|l|}
\hline & & B & Standard error & Sig. \\
\hline \multirow{5}{*}{ Model 1 } & (Constant) & 0.774 & 2.631 & 0.009 \\
\cline { 2 - 5 } & Physical Features & -0.013 & -0.160 & 0.873 \\
\cline { 2 - 5 } & Menu & 0.155 & 2.079 & 0.039 \\
\cline { 2 - 5 } & Service Brigade & 0.319 & 3.854 & 0.000 \\
\cline { 2 - 5 } & Management & 0.228 & 3.291 & 0.001 \\
\cline { 2 - 5 } & Ancillary Services & 0.171 & 2.121 & 0.035 \\
\hline \multirow{3}{*}{ Model 2 } & (Constant) & 0.771 & 2.633 & 0.009 \\
& Menu & 0.151 & 2.169 & 0.031 \\
\cline { 2 - 5 } & Service Brigade & 0.318 & 3.870 & 0.000 \\
\cline { 2 - 5 } & Management & 0.224 & 3.431 & 0.001 \\
\hline \multirow{2}{*}{ Dependent variable: } & loyalty & 0.169 & 2.138 & 0.034 \\
\hline
\end{tabular}

Source: The authors.

Observing the coefficients of Model 2, the Service Brigade factor has the greatest influence in the measure of Loyalty, with a value of 0.318 . The values of the other constructs are as follows: Management with 0.224; Ancillary Services with 0.169; and Menu with 0.151 .

That is, the factors related to service and direct contact with the guest, Service Brigade and Management, have the higher predictive power on Loyalty. Therefore, the hotel management must pay attention to maintaining the service quality of these areas. Table 8 shows the result of the equation to measure Loyalty through the predictors of food service quality.

Table 8 - Final result of the multiple regression equation

\begin{tabular}{|c|c|c|c|c|c|c|}
\hline LOYALTY & $=0.771$ & $\begin{array}{l}+0.151 \\
\text { Menu }\end{array}$ & +0.318 & $\begin{array}{l}\text { Service } \\
\text { Brigade }\end{array}$ & $\begin{array}{c}+0.224 \\
\text { Management }\end{array}$ & +0.169 \\
\hline
\end{tabular}

Source: The authors.

In order to generalize these results, it is necessary to check if the model fits the data well and if it is possible to generalize the conclusions. Firstly, we checked the outliers by observing standardized residuals. According to Field (2009) it is necessary to observe: (1) if more than $1 \%$ of the sample has absolute values greater than 2.50; and (2) if more than $5 \%$ of the sample has residuals greater than 2.00 , which indicates a poor fit of the sample data. The sample surveyed obtained nine cases with values higher than 2.00 , two of them with values above 2.50 . However, if a case has an outlier value, but the Cook's distance is less than 1.00 , there is no real reason to exclude this case because it does not have a big effect on the regression analysis. The Cook's distance considers the effect that a single case has on the model, i.e. as a measure of the global influence of the case in the model (Field, 2009; Stevens, 2002). In the nine cases filtered by the standardized residuals, as in the rest of the sample, there were no Cook's distance values greater than 1.00.

Subsequently, we have verified that the model represents the sample without excluding any case, thus, we proceeded to examine if it can be generalized; if so, it will be able to predict the same output variable (loyalty) with accuracy and using the same sets of predictive variables in a different sample of people. This is known as cross-validation. For this, we have compared the $R^{2}$ values of the model with the adjusted $R^{2}$ values, this difference represents loss of predictive power of the model (or shrinkage) (Field, 2009; Mann, 2015). In the model evaluated the $R^{2}$ value was 0.470 while the adjusted $R^{2}$ value was 0.460 . This difference represents only $1 \%$, showing that the adjusted model is very close to the original, and thus may be generalized.

Some theoretical implications arise from the results of this study. Contrary to the findings of the authors on whom we have based our research, the Physical Features construct did not prove significant in its power to predict the loyalty of guests. Barros (2013) describes the importance of Physical Features as a factor of attractiveness and safety to the customer, affecting his or her perception of quality and satisfaction. However, the author's study demonstrates, from the customers' perception, that attendance and quality of service are more important than the physical aspects. In the study by Peng, Chen, and Hung (2017), the hypothesis that the physical aspects affect the positive emotions regarding the customer experience is not confirmed, however they can negatively affect emotions. They have studied four-and five-star hotel restaurants; thus, 
customers can be dissatisfied if the physical aspects are worse than expected. However, they do not become excited or satisfied if the ambiance of the restaurant meets their expectations.

The study demonstrates the importance of problem-solving ability of the service team and management. This result is in line with other studies showing that customers value the service more than the product itself. Therefore, more staff training in customer service, complaints management, and efficiency are essential to achieve a high level of customer satisfaction, secure business, and the intention of returning to the establishment (Defranco et al., 2005, Ma et al., 2014). The aspects that refer to service were those with the greatest impact on loyalty intention, thus, strategies aimed at retaining customers should be adopted (Abdalla et al., 2013).

\section{Final considerations}

From the data discussed in this research, it can be assessed the importance of quality in the provision of food services and its impact on guest's intention of loyalty. Food service should focus on increasing the supply of suitable tourist products and on quality required to satisfy the needs of the guests. These will enjoy the services, so, it is important to offer products that will satisfy the growing demand and the different needs and, thus, increase the intention of loyalty.

This study examined the predictive power of food service quality elements on the intention of loyalty of the guests of a 4star Hotel in the city of Balneário Camboriú, SC. Among the aspects surveyed there are the predictive variables: Physical Features of the Environment; Quality of the Menu; Service Brigade; Management; Ancillary Services; and Customer Loyalty as a dependent variable (outcome). A good management of the variables referred in this article may lead to greater customer loyalty, who in turn will recommend the hotel to others. Through regression analysis the construct that has the best predictive power to evaluate Loyalty was Service Brigade with a coefficient of 0.318. The Physical Features construct was excluded from the model because the significance value was higher than 0.05 .

Providing quality services should be considered as an essential strategy for the success and survival of any company by recognizing quality factors that generate tourist satisfaction and subsequently influencing loyalty intention. Through common marketing sense the customer is more likely to recommend and return when they are satisfied with the quality of the service provided. Neto et al. (2009) concludes that the dissatisfied customer will probably not return and will generate a negative and more intense word of mouth than the satisfied ones. Hence, loyal customers, who make recommendations and intend to return, provide new business, decrease the expense with customer retention, among other competitive advantages.

In this study, some practical limitations must be considered. Firstly, geographical limitations, because the study was conducted only in a 4-star hotel in Balneário Camboriú, thus the conclusions are limited to this population. If the survey had included more establishments, the results could have been different. The following limitation is related to time issues, since the data collection was conducted for two months, not reflecting the effect of seasonality in tourism. The most significant limitation stems from the fact that the survey was implemented only during breakfast, thus not covering other meal times and without considering different service modalities such as à la carte, self-service and fixed menu.

Finally, it is worth emphasizing the need for further research in the areas examined in this study, but involving a larger number of hotels, extending to other populations and socio-cultural contexts, involving a greater number of participants in order to verify the generalization of these data, not limited to a specific cut-off as in the presented study.

There are several recommendations for future research that have emerged from this study, namely: to carry out the same study in other regions of the country; to conduct a study on customer perception of quality of other hotel services; and to develop a similar study where the guests' perceptions would be examined according to nationality. This model can be used by hotel managers as a tool to evaluate service provision and its reapplication can be used to assess the improvement on weak areas.

\section{References}

Abdalla, M. M., Altaf, J. G., Troccoli, I. R., Nóbrega, K. W. P., \& Cruz, G. F. da. (2013). Lealdade aos meios de hospedagem: um estudo com turistas de pousadas de Angra dos Reis (Rio de Janeiro, Brasil). Turismo \& Sociedade, 6(1), 79-103.

Araujo, A. O. (2001). Contribuição ao estudo de indicadores de desempenho de empreendimentos hoteleiros, sob o enfoque da gestão estratégica. São Paulo: Universidade de São Paulo e Faculdade de economia, administração e contabilidade.

Barreto, C. de J., \& Cé, N. (2014). Estudo da qualidade de serviços pferecidos em hotéis de Porto Alegre/RS: Oferta de alimentos isentos de glúten e lactose no café da manhã. Competência, 7(1), 79-95.

Barros, M. D. de. (2013). Dinnerperf: um modelo para avaliação e classificação da qualidade de serviços em restaurantes segundo a percepção dos clientes. Rio de Janeiro: Universidade Estadual do Norte Fluminense.

Behara, R. S., Fontenot, G. F., \& Gresham, A. B. (2002). Customer process approach to building loyalty. Total Quality Management, 13(5), 603-611. https://doi.org/10.1080/0954412022000002018

Cândido, Í., \& Vieira, E. V. de. (2003). Gestão de Hotéis: técnicas, operações e serviços. Caxias do Sul: EDUCS.

Castelli, G. (2003). Administração Hoteleira (9th ed.). Caxias do Sul: EDUCS.

Chand, M., \& Kapoor, B. (2014). A Comparative Study of Food and Beverage Service Practices in India Chain Hotels and Resorts. International Journal of Hospitality \& Tourism Systems, 7(1), 49-58.

Chin, J.-B., \& Tsai, C.-H. (2013). Developing a service quality evaluation model for luxurious restaurants in international hotel chains. Total Quality Management, 24(10), 1160-1173. https://doi.org/10.1080/14783363.2012.661132

Defranco, A., Wortman, J., Lam, T., \& Countryman, C. (2005). A Crosscultural comparison of customer complaint behavior in restaurants in hotels. Asia Pacific Journal of Tourism Research, 10(2), 173-190. https://doi.org/10.1080/10941660500135969 
Dick, A. S., \& Basu, K. (1994). Customer Loyalty: Toward an Integrated Conceptual Framework. Journal of the Academy of Marketing Science, 22(2), 99-113. https://doi.org/10.1177/0092070394222001

Ferro, R. C. (2013). Gastronomia e Turismo cultural: reflexões sobre a cultura no processo do desenvolvimento local. Contextos $D a$ Alimentação: Comportamento, Cultura e Sociedade, 2(2), 38-56.

Field, A. (2009). Descobrindo a estatística usando o SPSS (2nd ed.). Porto Alegre: Artmed.

Hair, J. F. J., Black, W. C., Babin, B. J., Anderson, R. E., \& Tatham, R. L. (2009). Análise multivariada de dados (6th ed.). Porto Alegre: Bookman.

Kotler, P., \& Keller, K. L. (2013). Administração de marketing (14th ed.). São Paulo: Pearson Education do Brasil.

Krause, R. W. (2014). Aspectos determinantes na percepção da qualidade dos serviços na experiência gastronômica turística. Caderno Virtual de Turismo, 14(1), 19-33.

Ma, E., Qu, H., \& Eliwa, R. A. (2014). Customer Loyalty with Fine Dining: The Moderating Role of Gender. Journal of Hospitality Marketing \& Management, 23, 513-535. https://doi.org/10.1080/19368623.2013.835250

Madanoglu, M. (2004). Validating restaurant service quality dimensions. Journal of Foodservice Business Research, 7(4), 127-147. https://doi.org/10.1300/J369v07n04

Mann, P. S. (2015). Introdução à estatítica (8th ed.). Rio de Janeiro: LTC. Neto, M. T. R., Filho, C. G., \& Cabral, L. M. (2009). Antecedentes Da Lealdade - Um Estudo Exploratório em Hotelaria para Negócios. Revista Turismo Visão E Ação, 11(1), 76-91.

Oliver, R. L. (1999). Whence consumer loyalty? The Journal of Marketing, 63, 33-44. https://doi.org/10.2307/1252099

Paladini, E. P. (2012). Gestão da qualidade: teoria e prática (3rd ed.). São Paulo: Atlas.

Parasuraman, A., Zeithaml, V. A., \& Berry, L. L. (1985). A conceptual model of service quality and its implications for future research. The Journal of Marketing, 49(4), 41-50. https://doi.org/10.2307/1251430

Peng, N., Chen, A., \& Hung, K. P. (2017). The effects of teppanyaki restaurant stimuli on diners' emotions and loyalty. International Journal of Hospitality Management, 60, 1-12. https://doi.org/10.1016/j.ijhm.2016.09.010

Petrocchi, M. (2007). Hotelaria: Planejamento e gestão (2nd ed.). São Paulo: Pearson Prentice Hall.

Rust, R. T., Zeithami, V. A., \& Lemon, K. N. (2003). A valor do cliente: $O$ modelo que está reformulando a estratégia corporativa. Porto Alegre: Bookman.

Schiffman, L. G., \& Kanuk, L. L. (2000). Comportamento do consumidor (6th ed.). Rio de Janeiro: Livros Técnicos e Científicos.

Silva, L. M. T. da, Medeiros, C. A. F., \& Costa, B. K. (2009). Qualidade Dos Serviços Turísticos No Setor De Restaurantes: Uma Aplicação Do Modelo Servperf. Revista Hospitalidade, 6(2), 115-139.

Soriano, D. R. (2003). The Spanish Restaurant Sector: Evaluating the Perceptions of Quality. The Services Industries Journal, 23(2), 183-194.

Stevens, J. (2002). Applied Multivariate Statistics for the Social Sciences (4th ed.). New Jersey: Lawrence Erlbaum Associates.

Trancoso, S. C. (2008). Desenvolvimento de instrumento para avaliação da qualidade nutricional e sensorial de bufês de café da manhã em hotéis de negócio. Santa Catarina: Universidade Federal de Santa Catarina.

Trancoso, S. C., Cavalli, S. B., \& Proença, R. P. da C. (2010). Café da manhã: caracterização, consumo e importância para a saúde. Revista de Nutrição, 23(5), 859-869. https://doi.org/10.1590/S141552732010000500016

Untaru, E.-N., Ispas, A., \& Neacsu, A.-N. (2012). Perceptions of Restaurant Managers About the Quality of Products and Services Offered to Consumers. Case Study: The City of Brașov. Journal of Tourism, (13), 5-13.
Received: 22.02 .2017

Revisions required: 16.10 .2017

Accepted: 12.02.2018 